\title{
Strength-based Design Analysis of a Para-Plow Tillage Tool
}

\author{
H. Kursat CELIK ${ }^{1 *}$, Nuri CAGLAYAN ${ }^{2}$, Mehmet TOPAKCI ${ }^{1}$, \\ Allan E. W. RENNIE ${ }^{3}$, Ibrahim AKINCI ${ }^{1}$
}

1, ${ }^{*}$ Dept. of Agricultural Machinery and Technology Engineering, Faculty of Agriculture, Akdeniz University, Turkey ${ }^{2}$ Dept. of Mechatronics Engineering, Faculty of Engineering, Akdeniz University, Turkey ${ }^{3}$ Engineering Dept., Lancaster University, United Kingdom

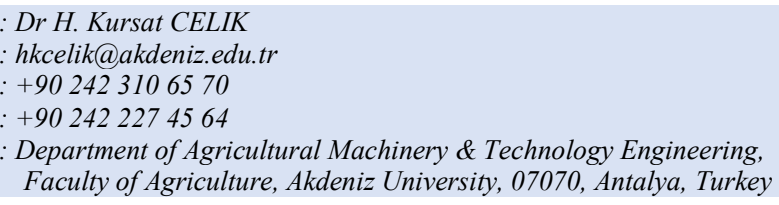

\section{Abstract}

In this research, experimental field tests and an advanced computer aided design and engineering (CAD and CAE) based application algorithm was developed and tested. The algorithm was put into practice through a case study on the strength-based structural design analysis of a Para-Plow tillage tool. Para-Plow is an effective tractor attached tillage tool utilised as an alternative to the conventional deep tillage tools used in agricultural tillage operations. During heavy tillage operations, the Para-Plow experiences highly dynamic soil reaction forces which may cause undesired deformations and functional failures on its structural elements. Here, prediction of the deformation behaviour of the tool structure during tillage operation in order to describe optimum structural design parameters for the tool elements and produce a functionally durable tool become an important issue. In the field experiments, draft force and strain-gauge based measurements on the tool were carried out simultaneously. Subsequently, Finite Element Method based stress analysis (FEA) were employed in order to simulate deformation behaviour of the tool under consideration of the maximum loading (worst-case scenario) conditions tested in the field. In the field experiments, average and maximum resultant draft forces were measured as $33,514 \mathrm{~N}$ and $51,716 \mathrm{~N}$ respectively. The FEA revealed that the maximum deformation value of the tool was $9.768 \mathrm{~mm}$ and the maximum stress values impart a change on the most critical structural elements of between 50 and $150 \mathrm{MPa}$ under a worst-case loading scenario. Additionally, a validation study revealed that minimum and maximum relative differences for the equivalent stress values between experimental and simulation results were $5.17 \%$ and $30.19 \%$ respectively. This indicated that the results obtained from both the experimental and simulation are reasonably in union and there were no signs of plastic deformation on the Para-Plow elements (according to the material yield point) under pre-defined loading conditions and a structural optimisation on some of the structural elements may also be possible.

This research provides a useful strategy for informing further research on complicated stress and deformation analyses of related agricultural equipment and machinery through experimental and advanced CAE techniques.

Keywords: Agricultural Machinery, Para-Plow, Design Analysis, Experimental Stress Analysis, Finite Element Analysis 


\section{Introduction}

As a specific branch of the machinery design and manufacturing industry, agricultural engineering considers the production and maintenance of tractors, agricultural machinery and agricultural implements/tools/equipment. It has gained more attention in recent years since global food/agricultural production has become vitally important in terms of feeding the world population. The current world population of 7.3 billion is estimated to reach 8.5 billion by $2030,9.7$ billion by 2050 and 11.2 billion by 2100 according to the UN DESA report: "World Population Prospects - The 2015 Revision" (UN DESA 2015). There is no doubt that, in order to produce sufficient volumes of food from currently available agricultural land, well-designed machinery and high-tech supported mechanisation for agricultural production is one of the most vital necessities. Most especially, the need for advanced computer aided design (CAD) and engineering (CAE) applications in the manufacturing processes in the agricultural engineering industry have important roles to play (Sha 2008). As such, it is fundamental that the agricultural engineering industry should be equipped with the most appropriate advanced design and manufacturing technologies in order that they can manage to provide sustainable, high-technology, higher precision and increased capacity machinery systems for efficient agricultural production in the finite land available.

CAD and CAE, structural optimisation and computer aided manufacturing (CAM) technologies have been used efficiently for product development, design and machinery manufacturing applications in related industries globally for a great number of years. These technologies provide important advantages in end-product time, product quality, manufacturing precision, design costs and the effective organisation of labour force issues in the overall product development and manufacturing processes. However, in many developing countries such as Turkey, most of the agricultural machinery manufacturers are classified as small and medium-sized enterprises (SMEs) that have not yet properly adopted advanced design technologies (Ileri 2018; AEA 2017) where limited research literature exists related to implementation strategies of advanced CAD and CAE applications. Thus, it is important that this research area is given the due consideration it deserves in order to develop robust design strategies, and to produce more efficient and structurally optimised agricultural machinery systems.

Soil tillage is one of the most important stages for the cultivation of crops in agricultural production. However, there are a number of problems that affect product yield negatively in seed bed preparation and production of plants in agricultural fields where soil compaction is experienced. In this context, producers use subsoiler and chisel tools in the fields where soil compaction is deemed problematic in agricultural production. These types of tools are classified as deep tillage equipment and require higher power and energy use compared to other tillage tools. Therefore, studies have been carried out for alternative tillage tools which may require less draft force, less fuel consumption and have a higher work efficiency in comparison to subsoiler and chisel tools. As a result of these studies, the Para-Plow tool was developed in the United Kingdom in recent years as an alternative to subsoiler and chisel tools and is also now receiving positive attention in Turkey. Previous studies support that the Para-Plow is a very efficient tillage tool in terms of time and energy saving in soil loosening (Krause et al. 1984; Ehlers and Baeumer 1988; Harrison 1988; Peterson et al. 1988, Pierce 1992, Parker et al. 1989; Sojka et al. 1997; Dorado and Fando 2006; Jafari et al. 2008; Friday 2008; Solhjou et al. 2014; Askari and Abbaspour-Gilandeh 2019). 
Although similar research studies regarding strength analysis of agricultural machinery/equipment and tillage tools can be found in recent literature (Topakci et al. 2010; Armin et al. 2014; Celik et al. 2017; Upadhyay et al. 2017; Jiang et al. 2018; Matache et al. 2019; Yurdem et al. 2019), detailed research on strengthbased design analysis and product development strategy for a Para-Plow tool by means of advanced CAD and CAE applications and the associated field validation and trials have not been undertaken previously. It therefore follows that an algorithmic design analysis study becomes necessary in order to design and manufacture more efficient and optimum machinery systems used in the agricultural fields as nowadays, more complex and largescale design engineering approaches and machinery applications are being requested by the industry.

Considering the limitations in the literature of advanced CAD and CAE applications related to the agricultural engineering field, most especially on advanced design analysis issues for a specific deep tillage tool (Para-Plow), this study aims to develop a CAD/CAE and experimental methods-based design analysis application algorithm and to conduct a strength-based design analysis case study on a Para-Plow tillage tool. With this aim, as detailed in this paper, an application algorithm was developed and put into practice in a step-by-step design analysis of an agricultural tillage tool (Para-Plow) in order to assist researchers and engineers who study the implementation of advanced $\mathrm{CAD}$ and $\mathrm{CAE}$ technologies within the agricultural design and manufacturing industry. In the study, experimental field tests and advanced CAD and CAE applications were employed. The study revealed useful design analysis outputs which may be used in structural optimisation studies of the Para-Plow.

\section{Materials and methods}

\subsection{Application algorithm}

In this research, an application algorithm which can be integrated to structural design analysis studies for applicable agricultural machinery and equipment such as tillage tools was developed and a case study on strengthbased design analysis of a Para-Plow tool was conducted. The algorithm was constructed based on experimental field tests, $\mathrm{CAD}$ and $\mathrm{CAE}$ techniques. The core application sequence of the developed algorithm is shown in Figure 1.

( Figure 1. Strength-based design analysis application algorithm for agricultural machinery )

\subsection{The Para-Plow tool}

The Para-Plow is a deep tillage tool whose fundamental design specification was prototyped in the UK by a group of agronomists, soil scientists and engineers (Krause et al. 1984; Harrison 1988; Friday 2008; Crook 2014). The most specific design feature of the tool is its tines with inclination up to $45^{\circ}$. The purpose of the Para-Plow is to loosen compacted soil layers at depths of 300 to $400 \mathrm{~mm}$ and maintain high surface residue levels. Para-Plowing should be effective at loosening soils that become compacted under the moist conditions of irrigation and thereby improve soil conditions for crop growth (Ewen 2015). The main structural elements of the tool are made from structural steel-based materials. Additionally, heat treatment is applied to the tine tips (plowshare). 
In the case study detailed in this paper, a Para-Plow tool with two tines which was manufactured by a company in Turkey was considered and specifically focused on a structural design analysis of the tool in order to understand the stress distribution on the tool elements and the total deformation behaviour under predefined test conditions. Key aspects of the technical and dimensional specifications of the Para-Plow tool considered in this research are given in Figure 2.

( Figure 2. Key aspects of the technical and dimensional specifications of the Para-Plow tool )

\subsection{Physical field experiments}

Physical experiments/field tests were carried out in order to measure the draft force and experimental stress magnitudes on specific locations of the tool under operational working conditions, which are related to the deformation behaviour experienced by the tool. In the field experiments, draft force and strain-gauge method-based stress measurements were conducted simultaneously. One of the most critical points in determination of strength-based design features of the machinery systems is consideration of the worst-case operating conditions and defining the range of the design variables accordingly, as the worst-case operating condition parameters may become the final design parameters. The measurements in the field experiments were realised in two stages. Firstly, the tool was operated in the nominal tillage depth $(350 \sim 400 \mathrm{~mm})$; secondly, the tillage depth was increased up to $25 \%$ (to $500 \mathrm{~mm}$ ) as the worst-case operating condition. This depth is also the greatest depth at which Para-Plow tines can work. Experimental data obtained from the field tests were used in the simulation studies in order to set up and validate the simulation results in addition to evaluation of the tool's physical deformation behaviour.

Field tests were carried out at the agricultural research field of Akdeniz University (Aksu-Antalya, Turkey). The experiments were set up on 3 ha $(200 \mathrm{~m} \times 150 \mathrm{~m})$ area. The area was divided into parts with $50 \mathrm{~m}$ divisions by signposts through the tillage direction (Figure 3). Dominant soil content in the field was clay. Additionally, some of the soil properties such as penetration resistance, moisture content and bulk density were also measured at the test field in order to fully ascertain the soil conditions during the tillage operation. Soil properties were measured at 10 different locations within the testing area. The soil penetration resistance was measured through a hand penetrometer (Eijkelkamp Sti Boka - max. measurement depth: $800 \mathrm{~mm}$; cone angle: $30^{\circ}$; penetrating speed of the cone: $30 \mathrm{~mm} \mathrm{~s}^{-1}$ ) in accordance with ASAE Standard EP542 (2002). Average values of the soil penetration resistance and related soil properties are given in Figure 3 against soil depth. The data measured indicated that maximum soil penetration resistance (Ci) was $3.59 \mathrm{MPa}$ at the working depth between $400 \mathrm{~mm}$ and $500 \mathrm{~mm}$ which would also be the maximum loading case during tillage for the tool used.

(Figure 3. Soil properties of the test field and testing scenario schematic )

Draft force measurements were conducted through a computer aided data acquisition system with bi-axial load-pin sensors. The system includes three bi-axial (horizontal and vertical) load-pins 
(BATAROW-MB397-75-A), 8-channel, 48-bit data acquisition module (ME-Meßsysteme GmbH-GSV-8), data recording and monitoring computer, electronic fasteners and data cables (Batarow 2019). The loading capacity of each load-pin was 75,000 N and the data sampling rate was $10 \mathrm{~Hz}$ during draft force measurement. Additionally, a special load-pin connector apparatus design was realised for attachment of the load-pins between the Para-Plow tool and the tractor hitch points. The draft force measurement system, its components and tractor attachment are shown in Figure 4.

( Figure 4. Components of the draft force measurement system and its tractor attachment ) 8

9

$$
\text { part of the field tests. Measured experimental strain data were converted to equivalent stress data according to the }
$$
relative engineering strain-stress conversion equations. Five SG rosettes were utilised in total which were placed onto the main frame and the tines of the Para-Plow tool. These measurement locations were selected considering the regions that could provide sufficient information about the deformation of the Para-Plow during tillage. During the strain measurement, HBM K-RY81-6 series three elements $\left(0^{\circ} / 45^{\circ} / 90^{\circ}\right) 120 \mathrm{ohm}$ rectangular SG rosettes, two modules of 8-channel, 24-bit HBM-QuantumX MX840A data acquisition modules, a data monitoring and recording computer, electronic fasteners and data cables were utilised. The data processing software of CATMAN was the 'on-the-go' monitoring interface during the tests (HBM $2011 \mathrm{a}, \mathrm{b})$. Simultaneous draft force and strain measurements were realised during pre-defined field test operations. $10 \mathrm{~Hz}$ data sampling rate was set up in order to record precise and synchronised data between draft force and strain measurements. The strain measurement system, its components and strain-gauge locations are shown in Figure 5.

( Figure 5. Components of the Strain-Gauge (SG) measurement system and SG locations on the Para-Plow )

For the first stage of the field experiments, tillage was carried out at a nominal working depth $(350 \sim 400 \mathrm{~mm})$, with average tractor speed of $4.5 \mathrm{~km} \mathrm{~h}^{-1}$. The Para-Plow cultivated soil at a tillage distance of $900 \mathrm{~m}$ (effective cultivated area: $675 \mathrm{~m}^{2}$ ). During the tests, draft force and strain measurements were recorded without pauses, including field turns, thus, the tool was physically tested in the field at a total tillage distance of 18 units $(900 \mathrm{~m})$ under nominal operating conditions.

One of the factors affecting the traction power during tillage is the speed of the tractor. However, in the tests carried out at a working depth of $500 \mathrm{~mm}$ during the second stage of the field experiments, it was observed that the tractor was excessively loaded with the nominal tillage working speed of $4.5 \mathrm{~km} \mathrm{~h}^{-1}$, the wheel skidding rate was higher than $40 \%$ and it was not possible to work at a constant tillage speed. For this reason, while working at increased tillage depth, the tool was able to be tested at an average tractor speed of $1.2 \mathrm{~km} \mathrm{~h}^{-1}$. The Para-Plow was operated at a tillage distance of three units at this increased tillage depth (approximately $150 \mathrm{~m}-$ effective cultivated area: $112.5 \mathrm{~m}^{2}$ ). The Para-Plow was overloaded for these increased tillage depth tests in accordance with the aim of the second stage of the field test. In fact, it was observed that it was very difficult to operate 
efficient tillage with the tool under these conditions. The tool was subjected to overloading other than for the design purpose; control of the movement of the tractor became difficult and it was deemed could have dangerous consequences for the loss of life and property. Hence, this case was approved as the worst-case loading scenario for the Para-Plow tool during tillage. A schematic demonstration of the computer aided data acquisition systems for draft force and strain measurements utilised in the field tests and pictures taken during field tests are shown in Figure 6. After completion of the field experiments, draft force and equivalent stress data obtained from the field experiments were recorded, precisely processed and represented numerically with graphical visuals. These visual outputs and the processed test data for draft force against equivalent stress values are given in Figure 7, Figure 8 and Table 1 respectively.

( Figure 6. Schematic demonstration of the computer aided data acquisition systems and the pictures taken during field tests of nominal (tillage depth: $400 \mathrm{~mm}$ ) and worst-case (tillage depth: $500 \mathrm{~mm}$ ) tillage operations )

(Figure 7. Field Test Results-01: Draft force and experimental stress values of nominal tillage condition )

(Figure 8. Field Test Results-02: Draft force and experimental stress values of worst-case tillage condition )

( Table 1. Draft force and equivalent (von Mises) stress values extracted from field tests )

\subsection{CAD Modelling and finite element analysis}

A reverse engineering approach was utilised to create a CAD model of the Para-Plow tool. All geometric features and functional limitations of the tool's elements were taken into consideration and solid models of the elements were created in a SolidWorks (SW) 3D parametric software environment using advanced solid modelling techniques. Thus, visual evaluations for the tool were successfully performed in the digital environment. One of the criteria used in the evaluation of the ability of the CAD models prepared to represent physical structures is the mass criterion. The total mass of the tool was calculated through the material property parameters which were defined in the solid modelling software. The total mass for the Para-Plow CAD assembly was automatically calculated as $610.22 \mathrm{~kg}$ by the software. When this value is compared with the tool's catalogue data of total mass $(600 \mathrm{~kg})$, it is considered that the CAD modelling operations were correctly conducted and the difference of $10.22 \mathrm{~kg}$ is an acceptable value relative to the total mass. After the completion of solid modelling and assembly operations, the Para-Plow tool was also evaluated in terms of suitability for manufacturing and physical assembly. In this assessment, the criteria such as the tractor attachment positions of the tool before, during and after tillage, tillage functionality, inter-elements compatibility, collision tests, degrees of freedom of the elements, and the stability during transportation etc. were considered and carefully examined. As a result of all the evaluations carried out, no problematic geometry regarding the Para-Plow CAD assembly was observed, hence the design was approved in order to perform finite element method (FEM) based structural analyses. Some statistical data related to the CAD assembly, visual outputs of the final CAD assembly and its tractor attachment are shown in Figure 9. 
For the strength analysis studies, in order to evaluate the failure conditions of the structural elements of a product, determination of the failure criterion is an important issue as designers make critical decisions on the final strength-based design of products according to such criterion. In both experimental and FEM based stress analyses of the Para-Plow tool considered in this research, the failure criterion was assumed to be the yield stress point of the material. In order to measure the yield point of materials used in the Para-Plow design, tensile testing was employed. The materials for the test specimens were collected from the manufacturer's stocks which were as assigned for the Para-Plow manufacturing. The specimens were extracted from three different samples of identical metal sheets (thicknesses of $2.5 \mathrm{~mm}, 6 \mathrm{~mm}$ and $8 \mathrm{~mm}$ ), and three specimens for each thickness, i.e. nine specimens in total were tested. Dog Bone Type 2 specimens were prepared and the tests were carried out according to TS EN ISO 6892-1 through the $100 \mathrm{kN}$ tensile capacity test device of SHIMADZU AG-X. The resultant data obtained from the tensile tests were processed, evaluated and average values were calculated in order to appoint them to the simulation set up respectively. According to this evaluation, the average yield, average ultimate tensile and average fracture stress points were 280.26 MPa, 404.23 MPa and 348.69 MPa respectively. Some of the visual and numerical details related to the tensile testing process and the results are given in Figure 10.

(Figure10. Material testing results and determination of failure criteria (material yield point) )

During the field tests, the Para-Plow was subjected to an excessive loading at the tillage depth of $500 \mathrm{~mm}$ which was defined as the worst-case loading scenario. Soil reaction forces reached the maximum value at this tillage condition, so the tool was forced to structurally deform more than the deformation magnitude experienced at the nominal tillage condition. The Finite Element Analysis (FEA) was set up in order to simulate the defined worst-case loading condition for the tool. ANSYS Workbench FEM based commercial analysis code was employed for the simulation. The FEA was set up under the assumptions of linear static loading and a linear homogeneous isotropic material model. Bonded and No Separation (sliding) linear contact types for welding locations and assembly surfaces were defined for the model respectively. The finite element (FE) model of the tool was created via meshing functions of the code. In order to obtain satisfactory levels of mesh quality with due consideration for structure size and computing platform capacity, pre-trials were realised and uniform meshing strategy was applied with the meshing parameters of maximum element size $(10 \mathrm{~mm})$, defeature size $(0.5 \mathrm{~mm})$ and element size growth rate (1.25). Total of 406,152 elements and 924,490 nodes were obtained in the FE Model of the tool. In order to verify the mesh quality of the FE model, a skewness metric was utilised in the code. Skewness is one of the primary quality measures for a mesh structure. Skewness determines how close to ideal a face or cell is. According to the definition of skewness, a value of 0 indicates an equilateral cell (best) and a value of 1 indicates a completely degenerate cell (worst) (ANSYS Doc. 2019). The average skewness metric value obtained was 0.245 which indicated an excellent cell quality for the FE model (Figure 11). Properties obtained from material tests were taken into consideration in the FEA. The yield strength measured from the material tests 
was approximately $280 \mathrm{MPa}$. This value was defined as the material failure criterion with Von Misses failure theory. In the FEA operations, a structural steel-based material was defined with the material parameters of modulus of elasticity (210 GPa), Poisson's ratio (0.3), and the material density $\left(7850 \mathrm{~kg} \mathrm{~m}^{-3}\right)$. A Dell Precision M4800 series mobile workstation was used as the solving platform (Intel Core i7-4910Q-2.9 GHz, 32 GB RAM, NVIDIA Quadro K2100M-2GB, DDR5). Boundary conditions and details of the FE model are given in Figure 11.

(Figure 11. Boundary conditions assumed in the FEA, details and verification (Skewness check) of the FE model )

After completion of the pre-processor steps such as solid modelling, material definition, boundary conditions and preparation of the FE model, the FEA was run. The FEA solution showed the visual deformation behaviour of the tool and equivalent (Von Mises) stress distributions on the tool elements in detail. According to the results, the maximum deformation (displacement) value was $9.7687 \mathrm{~mm}$ for the whole structure. When it is compared with the Para-Plow dimensions, it was interpreted that this deformation magnitude would not be detrimental for an effective tillage operation and could be considered within acceptable design limits under predefined loading conditions. In the analysis of the strength limits of the tool, it was investigated whether the material yield strength $(280 \mathrm{MPa})$ was exceeded or not at any point of the whole Para-Plow structure, as the yield point is the critical threshold to failure phenomenon for the materials. Although no abnormality was witnessed on the deformation behaviour of the tool, simulations results highlighted excessively high stress concentrations on some single elements at sharp corners and lineal contact regions. Therefore, the stress analysis results identified for these regions were re-investigated. As a result of these subsequent deeper investigations, it was determined that the stress magnitudes were excessively high and the results were not proportional against the pre-defined loading conditions and displacements calculated. Here, the simulation results were re-checked to determine whether any methodical or numerical errors might be experienced in the FEA of the Para-Plow. In a FEA study set up in order to represent pre-defined real physical conditions, numerical errors may occur during the establishment of the mathematical model $\left(\mathrm{e}_{1}\right)$, the mathematical discontinuity $\left(\mathrm{e}_{2}\right)$, and the numerical solution processes ( $\left.\mathrm{e}_{3}\right)$ (Figure 12) (Salmi 2008; Narasaiah 2008; Pancoast 2009). In addition to these methodical errors that might be experienced during a FEA study, user-based errors can occur during interpretation of the results, so should also be kept under consideration. Most especially, FEA solutions utilised for structural stress analysis, excessive and meaningless stress concentrations on sharp corner and contact locations, which is known as a stress singularity, may be experienced. In order to represent an ideal physical structure in a FEA simulation, the common approach is using a smaller element size at the critical loading locations with sharp corners, constraint points or contact regions in the FE model, however, in the stress singularity cases experienced in a FEA solution, an increase in stress values against constant displacement values at these specific locations are observed (Andy's Log 2012; Grieve 2006 ). The singularity can be calculated on a critical element which experiences excessively high stress values at a critical location in a FEA solution. The singularity can be diagnosed if the relative difference between stress values measured at two corner points on an identified single element is greater than $30 \%$. In this scenario, the excessive stress values on related locations can be ignored (Souza et al. 2011). 
A stress singularity case in the FEA of the Para-Plow tool was explored in accordance with related scientific literature (Huebner et al. 2001; Andy's Log 2012; Coskun and Soyhan 2011, SolidWorks Doc. 2011, Souza et al. 2011). The singularity control showed that cases on some elements (specifically on two elements: tine connection plates and a welding point on the main frame) in the FEA of the Para-Plow was diagnosed and these values were ignored in the evaluation of the stress analysis results. Errors in FEA approach, the calculation method for singularity diagnosis and a singularity example experienced in the Para-Plow analysis are given in Figure 12.

Numerical methods and engineering simulation studies are very useful in visualising more detailed information than experimental and analytical analysis, however some assumptions have to be kept under consideration in the numerical method-based solutions. These assumptions may lead to some of the errors mentioned above. Here the stress analysis results for a Para-Plow were successfully evaluated, singularity-based errors were eliminated and deformation behaviour of the tool was successfully simulated under a defined worstcase loading scenario. Except for singularity points calculated in the FEA results, it was observed that the equivalent stress values on the tool elements were under the limit of the failure criterion. In accordance with the yield point of the material, safety factor distributions on the tool were also calculated. This calculation revealed that there was no plastic deformation evident on the tool elements and the safety factors on the tool elements had a change between 2 (approx.) and 15. The simulation output including deformation, equivalent (Von Mises) stress, safety factor plots and stresses at SG locations are given in Figure 13.

( Figure 12. General errors in a FEA approach, singularity check and sample singularity calculation from the FEA results of the Para-Plow )

( Figure 13. Output results of the FEA: Equivalent stress distribution, safety factor distribution and deformation distribution )

\section{Results and discussion}

Structural design analysis of the Para-Plow tool was successfully carried out by means of experimental and numerical method-based stress analyses. However, a validation study is an important part of an efficient FEA study in order to evaluate and scale reliability and accuracy of the simulation results against real-life physical conditions as the numerical method-based simulations are described as an approximation method for complex engineering problems. In this regard, a validation study was carried out in order to scale the reliability and accuracy of the FEA set up for the Para-Plow. In the validation study, stress analysis results at the SG locations obtained from experimental and simulation studies were compared. Reliability and accuracy of the simulation results were scaled against experimental results by performing calculations for relative differences in percentage at the SG locations. The relative difference in percentage was calculated according to Equation 1 given below (Kurowski and Szabo 1997). 
Here, $\sigma_{\text {Exp }}$ and $\sigma_{\text {FEA }}$ are experimental and the FEM based equivalent (Von Mises) stress analysis results in MPa calculated at the specific SG locations respectively.

The validation calculations revealed that relative differences in percentage between experimental and FEA equivalent stress results at the SG locations were $30.19 \%$ (SG-01), $11.72 \%$ (SG-02), 5.36\% (SG-03), $5.17 \%$ (SG-4) and $7.30 \%$ (SG-05) respectively. The numerical results of the calculations were represented by a double axis chart as given in Figure 14. Research studies in the literature indicate that acceptable relative differences in percentage between experimental and simulation studies may vary up to $30 \%$ depending on the complexity of the physical environment to be simulated (Caliskan 2011; Celik et al. 2012; Sivaraos et al. 2015; Celik et al. 2017; Yurdem et al. 2019). For instance, Yurdem et al (2019) reported an experimental (strain-gauge) and FEM-based structural stress analysis study on a three-bottom moldboard plough. A good correlation between FEA and the field test and a weight reduction on the tool elements were reported as positive outputs of the research. The validation error percentage between FEA and the experiments were between $6 \%$ and $29 \%$ (approximately) against draft force of 20,000 N (tillage depth: $250 \mathrm{~mm}$ ) in their study. This percentage in the validation study seems compatible with the values obtained in the Para-Plow study (Figure 14). Besides this, there is belief that the acceptable relative difference rate of a healthy FEA approach should be less than $10 \%$ (Krutz et al. 1984; Sakakibara 2008). However, it should be considered that the differences between experimental and simulationbased results can vary dependent on analysis type, geometry idealisation level, FE model, boundary conditions set up in a FEA and unpredictable physical conditions during the experiments. The scale of the absolute numerical results against the failure criteria should also be kept under consideration. Therefore, the comparative evaluation of the experimental and FEA results should be carried out taking into account the factors mentioned above.

As such, although the relative difference of $30.19 \%$ at the SG-01 location appears greater than may be expected, the absolute stress values for experimental and FEA results were quite close to each other at this SG location (8.28 MPa and 10.78 MPa respectively). The absolute difference was $2.50 \mathrm{MPa}$ which may be thought of as an insignificantly small value against the failure criteria (280 MPa). In this context, it can be confirmed that the validation study revealed that experimental and simulation results exhibited good correlation within an acceptable range.

The equivalent stress distribution on the Para-Plow tool was successfully exhibited through FEA simulation. The results indicated that the failure threshold (material yield stress point) was not exceeded at any location on the tool elements except for a couple of singularity points where singularity diagnoses were approved by related calculations. Except for these singularity locations (which could be ignored), the maximum stress 
locations have sharp and thin geometries and it was very logical to expect higher stress values at these locations. Safety factor calculations indicated that the rest of the elements have very high values up to 15 which might be an indicator for a structural optimisation study with the objective of reducing the material weight. Matache et al (2019) carried out a FEA on a newly designed and manufactured deep tillage tool (MAS-65). In their study, the maximum structural deformation of the tool was determined as $5.795 \mathrm{~mm}$ against draft force magnitude of 13,573 N (tillage depth: $450 \mathrm{~mm}$ ). In the case study detailed in this paper, maximum deformation was calculated as $9.768 \mathrm{~mm}$ against draft force magnitude of $51,716 \mathrm{~N}$ (tillage depth: $500 \mathrm{~mm}$ ), so the global deformation magnitude of the Para-Plow may be considered relatively lower than their design in a linear approach, which is an indication of a more durable structure during deep tillage operation.

Advanced CAD and CAE simulations supported with physical field tests and related manufacturing applications in the agricultural machinery manufacturing industry are very limited in the area of design of agricultural machinery and related agricultural mechanisation systems, most especially in developing countries. In this research, an application algorithm based on experimental and advanced CAE techniques was developed and a case study for a Para-Plow tillage tool was successfully realised. In the case study, physical tests, CAD and CAE applications were applied step-by-step, numerical and visual results were exhibited and FEA evaluation techniques were discussed, hence, a successful design analysis study in order to generate an optimum design was successfully achieved. The advanced engineering processes described in the case study would be very useful for increasing the product quality, ensuring savings in design, testing and manufacturing times, having efficient work and maximum profits by reducing the material wastage. This case study would also be appropriate as a 'how-to' strategy for researchers and engineers in academia and industry. A successful design analysis study for different agricultural machinery and equipment used in tillage, seeding, harvesting and transportation would be realised through the methods, application algorithm and physical and digital test strategies covered by this research. This research also has an active role in order to improve industrial design strategies with well-designed effective products through a university-industry collaboration.

\section{Conclusions}

In this research, the aim was to describe strength-based structural design features which may be used in the structural design studies of a new Para-Plow tool nominated as an effective alternative tool to subsoiler and chisel tools especially in agricultural fields that have experienced soil compaction problems. Within the scope of this research, an application algorithm was developed based on CAD, CAE techniques and experimental methods that can be used in the total design development, improvement and structural optimisation processes of the Para-Plow and similar agricultural machinery, tools and equipment. In this manner, the aim of the research was accomplished and a successful case study was represented.

In the case study, physical field tests compatible with $\mathrm{CAD}, \mathrm{CAE}$ and structural optimisation techniques were performed on the Para-Plow. The results obtained from the physical tests were compared with the results of the simulation and the design validation results were represented. The modelling stage of the case study did not experience any assembly errors or difficulties as advanced CAD modelling techniques were applied and digital models were successfully created. Failure risks on the materials were clearly exhibited through FEA simulations. Additionally, structural optimisation indicators and the feasibility of reducing the material weight and total cost of 
the tool were discussed. Design validation of the tool was successfully realised through physical field tests and tillage efficiency of the tool was tested. No functional disturbance on the tool during tillage was observed. The FEA was validated by experimental results and showed that they have a good correlation within material limit values. In this research, advanced applications related to CAD and CAE technologies in the agricultural machinery research field have been successfully exemplified.

In consideration of small and medium sized enterprises, although advanced engineering applications supported by CAD / CAE are widely used in other machinery design and manufacturing industries, it cannot be said that they are effectively used in the design and manufacturing of agricultural machinery. Hence, use of these types of CAE applications and methodologies in the agricultural machinery industry would be very useful in terms of generating optimum design, incurring less time and cost losses and scientific verification and improving global marketing skills. Thus, it would be possible to contribute to the development of the agricultural machinery design and manufacturing industry.

\section{Acknowledgements}

This research study was supported financially by The Scientific Research Projects Coordination Unit of Akdeniz University (Turkey) Grant number: FBA-2015-601, 2015. Additionally, the authors wish to acknowledge contribution of Lancaster Product Development Unit (LPDU) at Lancaster University (United Kingdom) in technical evaluation processes employed in this research paper. 


\section{References}

Andy's Log. 2001. Stress Singularities. Online: http://andreweib.wordpress.com/2010/12/14/stress-singularities/ (Last Accessed: 12.09.2019)

ANSYS Documentation, 2019, Meshing User's Guide: Skewness. Release 2019 R2, ANSYS Inc., USA.

Armin, A., Fotouhi, R., Szyszkowski, W. 2014. On the FE modelling of soil-blade interaction in tillage operations, Finite Elements in Analysis and Design, Vol. 92, 1-11

ASAE Standards, 49th ed. 2002. EP542. Procedures for using and reporting data obtained with the soil cone penetrometer. St. Joseph, Mich.: ASAE.

Askari, M. and Abbaspour-Gilandeh, Y. 2019. Assessment of adaptive neuro-fuzzy inference system and response surface methodology approaches in draft force prediction of subsoiling tines, Soil \& Tillage Research, 194 (2019) 104338

Batarow, 2019, Available URL: http://www.batarow.com/en/ (Last Accessed: 03.09.2019)

Calışkan, K. 2011. Traktör emniyet çerçevesinde dayanım optimizasyonunun laboratuvar test sonuçları ile doğrulanmış sonlu elemanlar yöntemi simülasyonu yardımıyla gerçekleştirilmesi. Doktora Tezi. Ege Üniversitesi, FBE, İzmir, 91 s. (In Turkish)

Celik, H. K., Caglayan, N., Cinar, R., Ucar, M., Ersoy, H., Rennie. A. 2012. Stress Analysis of a Sample Marine Crane's Boom Under Static Loading Condition. 5th International mechanical engineering forum (IMEF2012), Prague, CzechRep., ISBN 9788021322912. 246-256.

Celik, H.K., Rennie, A.E.W., Akinci, I. 2017. Design and structural optimisation of a tractor mounted telescopic boom crane. J Braz. Soc. Mech. Sci. Eng. 39:909-924, DOI 10.1007/s40430-016-0558-y.

Coşkun, G. ve Soyhan, H.S. 2011. Sonlu elemanlar ağ yöntemi yaklaşımına dayalı kenar civarındaki gerilim dağılımlarının tekillikleri. Mühendis ve Makine, 52 (614): 116-125.

Crook, I.D. 2014. The Howard Para-Plow. Victorian Sales Manager, Crop Protection ICI Australia Operations Pty Ltd. Bayswater, Vic. 3153. Available URL: http://www.regional.org.au/au/roc/1984/roc198467.htm (Last Accessed: 02.09.2019)

Dorado, J. and Lopez-Fando. C. 2006. The effect of tillage system and use of a Paraplow on weed flora in a semiarid soil from central Spain, Weed Research 46, 424-431.

Ehlers, W. and Baeumer, K. 1988. Effect of the Paraplow on Soil Properties and Plant Performance ISTRO 11th International Congress: Tillage Traffic in Crop Production), Vol. 2, 637-642.

Ewen, B.M. 2015, Effect of Para-Plowing on Soil Properties and Crop Yield under Irrigated Management. MSc Thesis, Department of Soil Science, University of Saskatchewan, Saskatoon, Saskatchewan, Canada, P75.

Friday, N.W., Davis H.B., Dey, A.D. 2008. Simon and P. Mc Farlane, Reduced Tillage Systems For Heavy Coastal Clay Soils in The Guyana Sugar Industry, XXIX Conference of West Indies Sugar Technologists, Montego Bay, Jamaica, April 21-25, 2008.

Grieve, D.J. 2006. Errors Arising in FEA. Online: http://www.tech.plym.ac.uk/sme/mech335/feaerrors.htm

Harrison, P.H. 1988. Soil Reacting Forces for a Bentleg Plow, Transactions of the ASABE. 31 (1): 0047-0051. (DOI: 10.13031/2013.30663)

HBM 2011a. Datasheet: QuantumX MX840A. Doc. No: B2924-2.0 en. Hottinger Baldwin Messtechnik GmbH, Germany. 
HBM 2011b. Strain Gages and Accessories. Doc. No: S 1265-1.0 en. Hottinger Baldwin Messtechnik GmbH, Germany, $100 \mathrm{~s}$.

Huebner, K.H., Dewhirst, D.L., Smith, D.E., Byrom, T.G. 2001. The Finite Element Method for Engineers. John Wiley \& Sons. ISBN: 9780471370789,744 p.

Ileri, M.S. 2018. TARMAKBIR (The Turkish Association of Agricultural Machinery \& Equipment Manufacturers) Sector Report 2018 for Turkish Agricultural Machinery Industry (05.02.2018; Revision 22.02.2019)

Jafari R., Raoufat M.H., Tavakoli Hashjin T. 2008. Soil-Bin Performance of a Modified Bent Leg Plow, Applied Engineering in Agriculture. 24(3)): 301-307. (DOI: 10.13031/2013.24493)

Jiang, Q., Xu1, L., Xue, B., Zhang, Z. 2018. Design and analysis of a bionic pull-type subsoiler, Academic journal of manufacturing engineering, vol. 16, (4), 46-53.

Krause, R., Lorenz, F., and Hoogmoed, W.B. 1984. Soil Tillage in the Tropics and Subtropics, Eschborn. Published by Deutsche Gesellschaft fur Technische Zusammenarbeit (GTZ) GmbH, Germany, p.320.

Krutz, G., Thompson, L., Claar, P. 1984. Design of Agricultural Machinery. John Willey \& Sons, ISBN: $047108672,473 \mathrm{~s}$.

Kurowski, P. and Szabo, B. 1997. How to find errors in finite element models. Machine Design, 9: 93-98

Matache, M.G., Remus, M.O., Dragos, N.D., Gheorghe, G V., Cujbescu, D., and Persu, C. 2019. Structural analysis of deep soil loosening machine MAS-65. Les Ulis: EDP Sciences. DOI:http://dx.doi.org/10.1051/e3sconf/201911203034

Narasaiah, L.G. 2008. Finite Element Analysis. BS Publications. ISBN:9788178001401, 340 p.

Pancoast, D. 2009. Solidworks Simulation-2010 Training Manual. Dassault System Solidworks Corporation. Doc. No: PMT1040-ENG. 486 p.

Parker, C., J., Carr. M.K.V., Jarvis, N.J., Evans, M.T.B. and Lee, V.H. 1989. Effects of subsoil loosening and irrigation on soil physical properties, root distribution and water uptake of, potatoes (Solanum tuberosum). Soil and Tillage Research 13, 267-285.

Peterson, A., E., Swan, J.B., Paulson N.H. and Higgs, R.L., 1988. Effect of Modern Tillage Systems On Residue Management For Corn Production. ISTRO 11th International Congress: Tillage Traffic in Crop Production, 11-15th july 1988, vol. 2, 809-814.

Pierce, F.J., Fortin, M.C. and Staton, M.J. 1992. Immediate and Residual Effects of Zone-Tillage on Soil Physical Properties and Corn Performance. Soil and Tillage Research 24, 149-165.

Sakakibara, N. 2008. Finite Element in Fracture Mechanics. Lecture Notes. The University of Texas, Austin, USA.

Salmi, S. 2008. Multidisciplinary Design Optimization in an Integrated CAD/FEM Environment. MSc Thesis, Dept. of Mathematical Information Technology, University of Jyvaskyla. 70 p.

Sha, L. 2008. An application of industrial design in large-scale agricultural machinery. 9th International Conference on Computer-Aided Industrial Design and Conceptual Design, Kunming, China, DOI: 10.1109/CAIDCD.2008.4730688, pp. 823-828.

Sivaraos, S.T., Leong, Y., Yusof, C., Tan, F. 2015, An experimental and numerical investigation of tensile properties of stone wool fiber reinforced polymer composites, Adv. Mater. Lett. 6(10), 888-894

Sojka, R.E., Horne, D.J., Ross, C.W. and Baker, C.J., 1997. Subsoiling and Surface Tillage Effects on Soil Physical Properties and Forage Oat Stand and Yield. Soil and Tillage Research 40, 125-144. 
Solhjou, A., Fielke, J.M., Desbiolles, J.M.A., and Saunders, C. 2014. Soil translocation by narrow openers with various bent leg geometries. Biosystems Engineering, 127, 41e49.

SolidWorks Documentation. 2011. SolidWorks Simulation. Training Manual Document No: $015600018017-$ PMT1140-ENG-DRAFT, Dassault Systems SolidWorks Corporation, USA, 486 p.

Souza, T., S.G., De Souze, M. M., Savoy, J. 2011. Stress Singularity Issue in the Virtual Development of Powertrain Parts. Virtual Powertrain Conference and Expo, 24 25, August 2011. Sao Paulo, Brazil.

The Agricultural Engineers Association (AEA), 2017, Market Report 2017: Overview of the Agricultural Engineering Market 2017, Available URL: http://www.aea.uk.com/news-home (Last Accessed: 02.03.2019)

Topakci, M., Celik, H.K.; Canakci, M., Rennie, A.E.W., Akinci, I., Karayel, D. 2010. Deep tillage tool optimization by means of finite element method: Case study for a subsoiler tine, Journal of Food, Agriculture \& Environment Vol.8 (2): 531-536.

UN DESA, 2015. World population prospects-the 2015 revision: Key findings and advance tables. Dept. of Economic and Social Affairs-Population Division, United Nations, Doc. No. ESA/P/WP.241, New York, USA.

Upadhyay, G., Raheman, H., Rasool, S. 2017. Three Dimensional Modelling and Stress Analysis of a Powered Single Acting Disc Harrow Using FEA, Current Agriculture Research Journal, Vol. 05 (2), 203-219.

Yurdem, H., Degirmencioglu, A., Cakir, E., Gulsoylu, E. 2019. Measurement of strains induced on a three-bottom moldboard plough under load and comparisons with finite element simulations, Measurement, Vol.136, 594602 
541 Figure 1. Strength-based design analysis application algorithm for an appropriate agricultural machinery

542 Figure 2. Key aspects of the technical and dimensional specifications of the Para-Plow tool

543 Figure 3. Soil properties of the test field and testing scenario scheme

544 Figure 4. Components of the draft force measurement system and its tractor attachment

545 Figure 5. Components of the Strain-Gauge (SG) measurement system and SG locations on the Para-Plow

Figure 6. Schematic demonstration of the computer aided data acquisition systems and the pictures taken during field tests of nominal (tillage dept: $400 \mathrm{~mm}$ ) and worst-case (tillage dept: $500 \mathrm{~mm}$ ) tillage operations

548 Figure 7. Field Test Results-01: Draft force and experimental stress values of nominal tillage condition

Figure 8. Field Test Results-02: Draft force and experimental stress values of worst-case tillage condition

Figure 9. Some statistical details and visuals from the Para-Plow CAD Modelling Procedures

Figure10. Material testing results and determination of failure criteria (material yield point)

Figure 11. Boundary conditions assumed in the FEA, details and verification (Skewness check) of the FE model

Figure 12. General errors in a FEA approach, singularity check and sample singularity calculation from the FEA results of the Para-Plow

Figure 13. Output results of the FEA: Equivalent stress distribution, safety factor distribution and deformation distribution

Figure 14. Validation study: Comparison of the experimental and the FEA stress results at SG locations

Table 1. Draft force and equivalent (von Mises) stress values extracted from field tests 
56

565

566

567

568

569

570

571

572

573

574

575

576

577

578

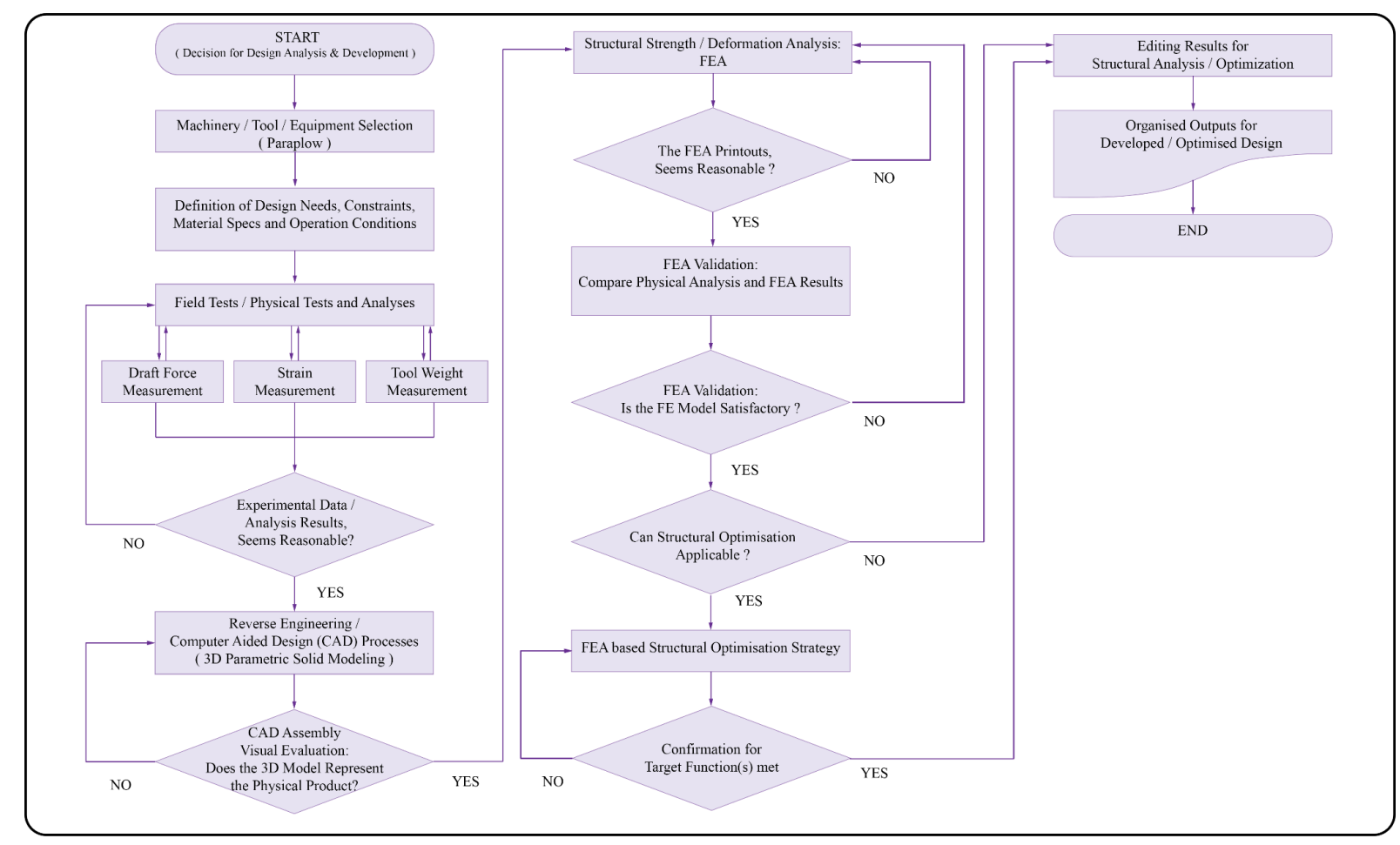

Figure 1. Strength-based design analysis application algorithm for an appropriate agricultural machinery 


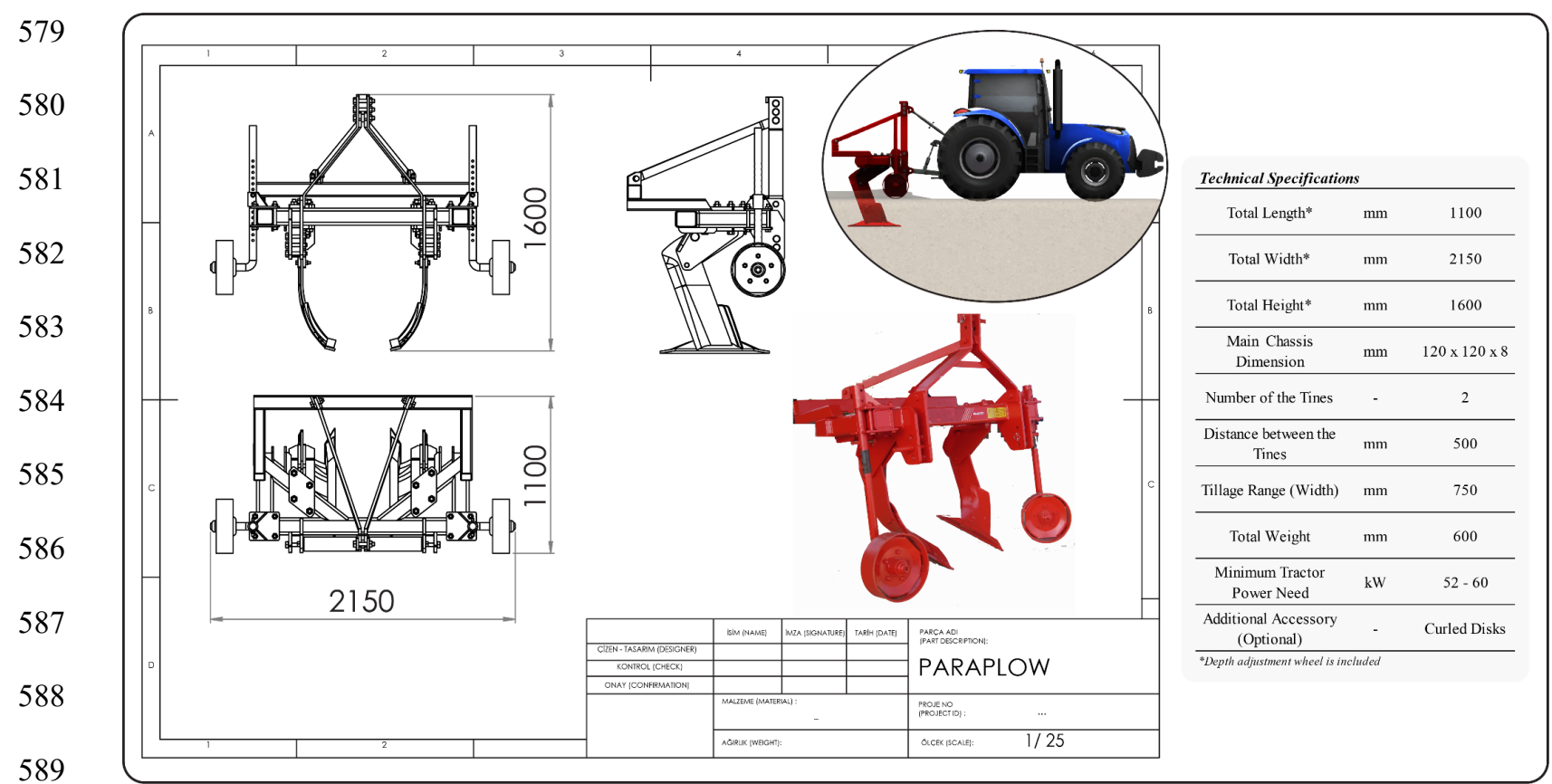

Figure 2. Key aspects of the technical and dimensional specifications of the Para-Plow tool 
593

594

595

596

597

598

599

600

601

602

603

604

606

608

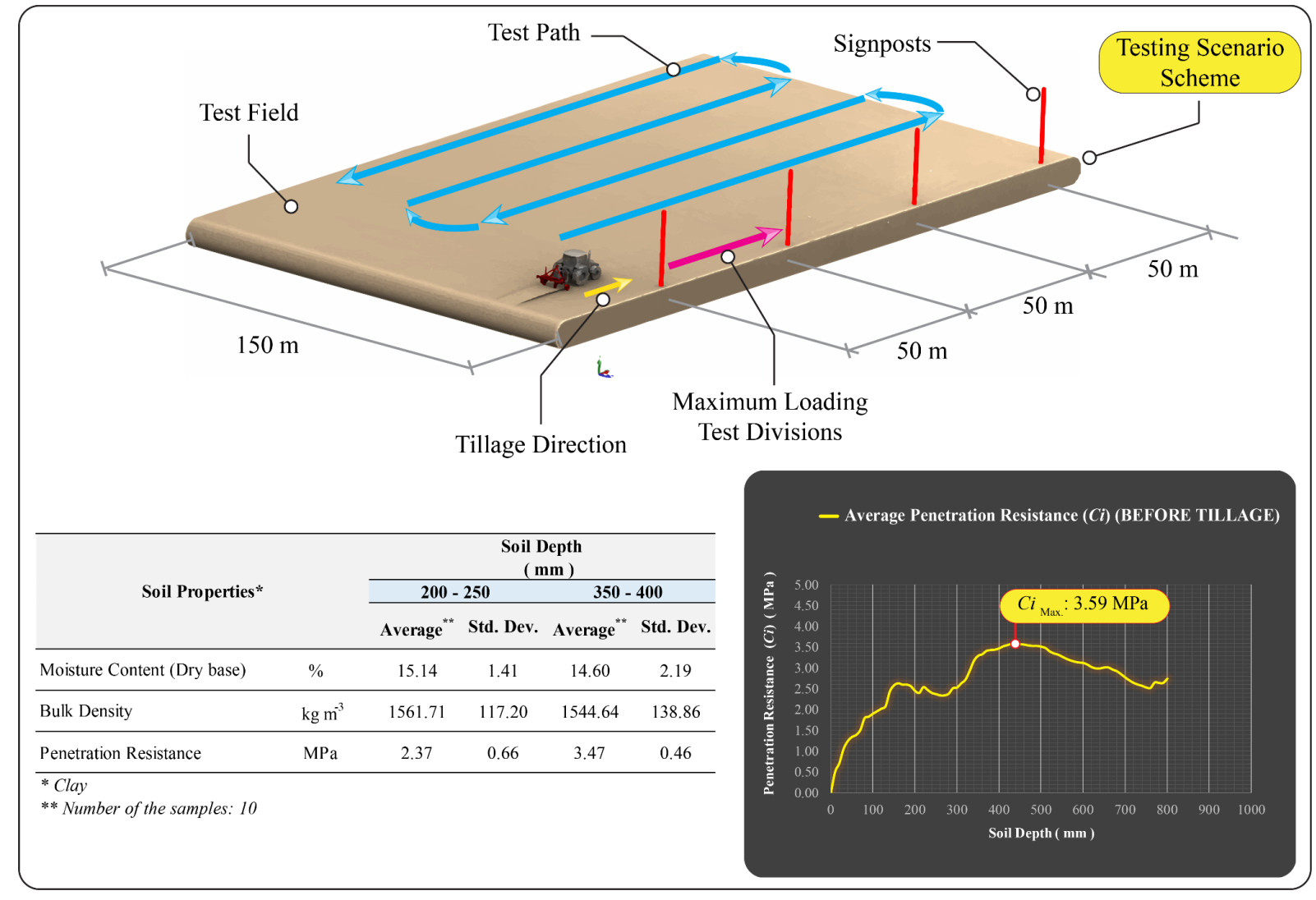

Figure 3. Soil properties of the test field and testing scenario scheme 


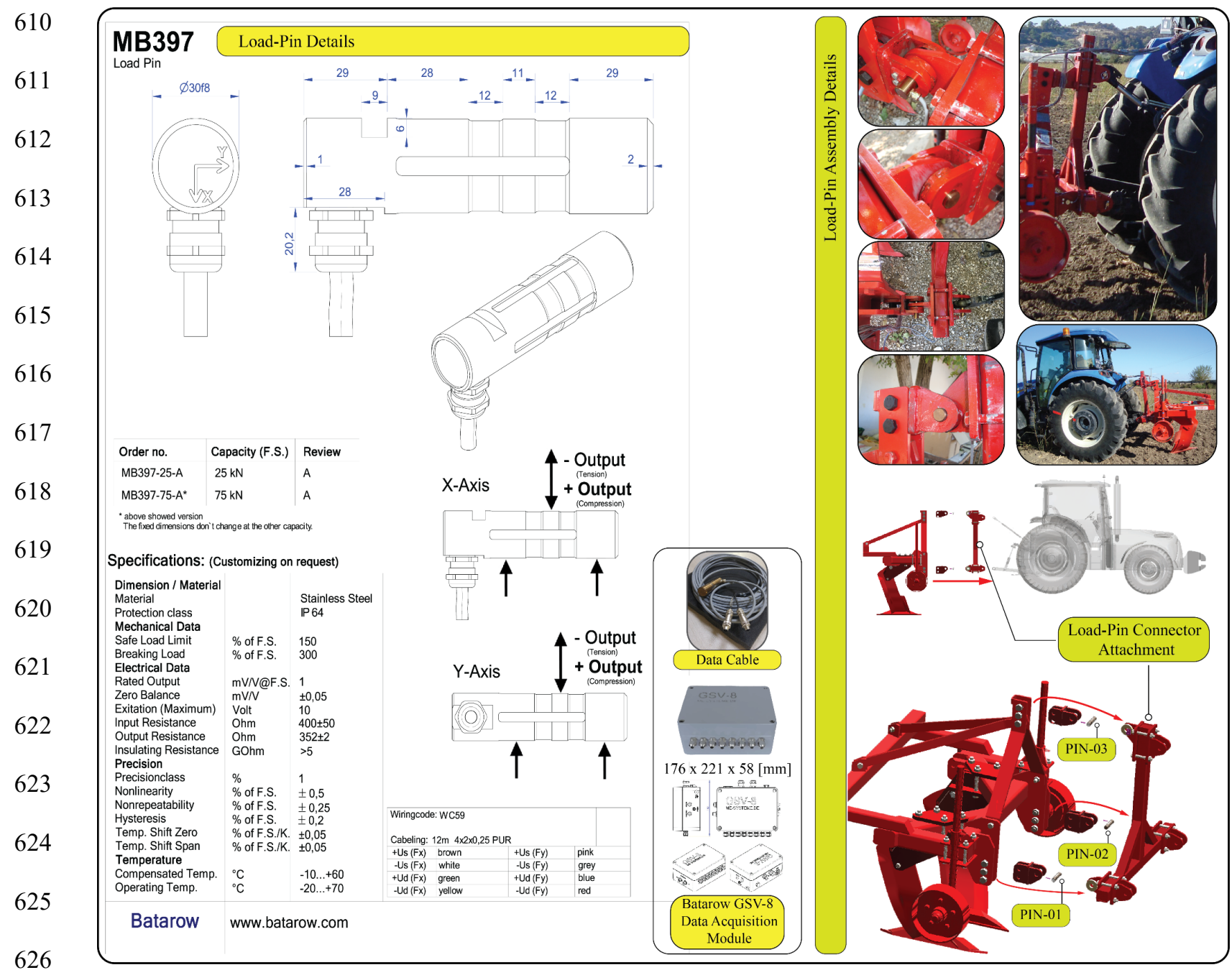

627

Figure 4. Components of the draft force measurement system and its tractor attachment 


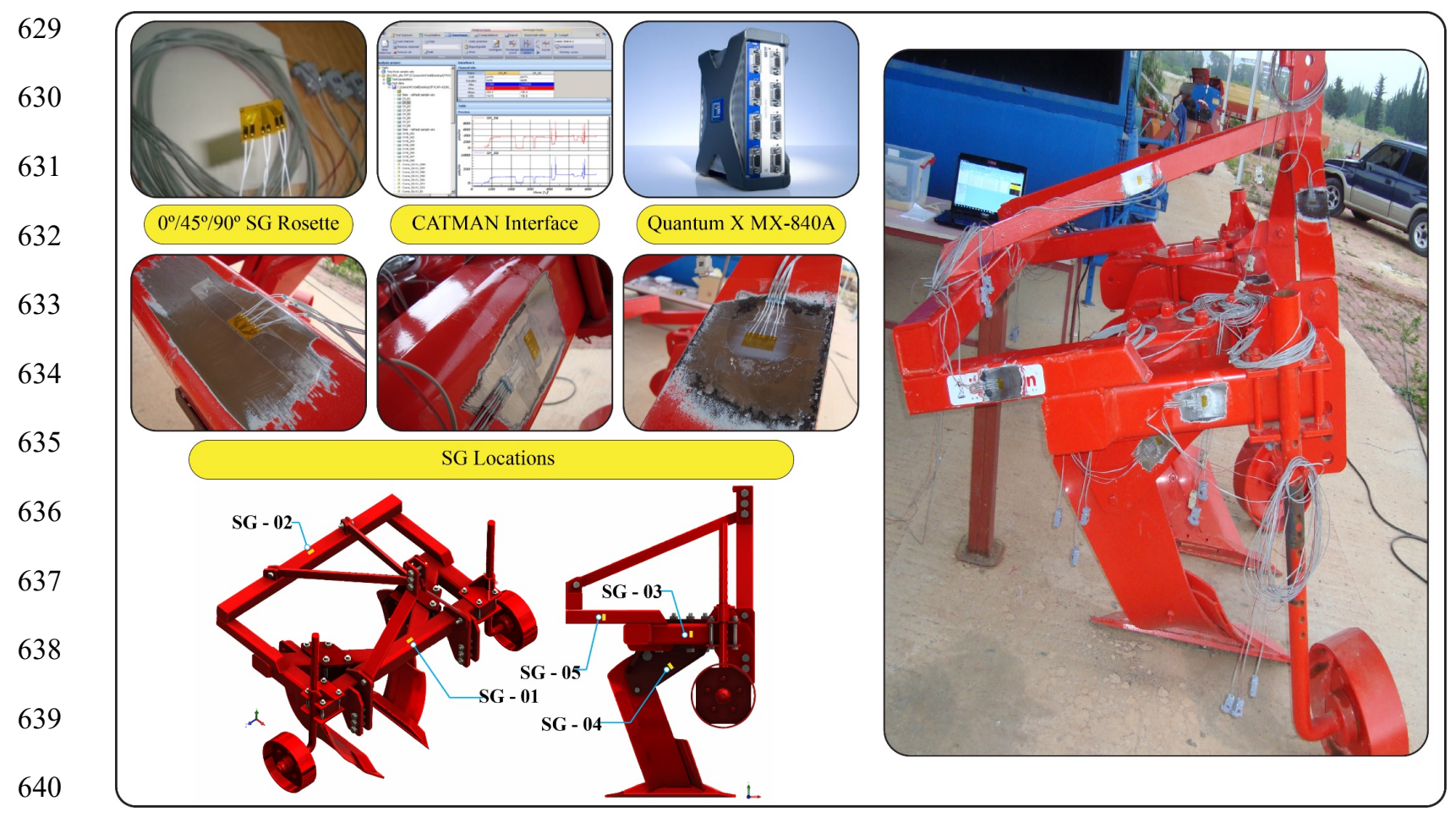

641

Figure 5. Components of the Strain-Gauge (SG) measurement system and SG locations on the Para-Plow 643 


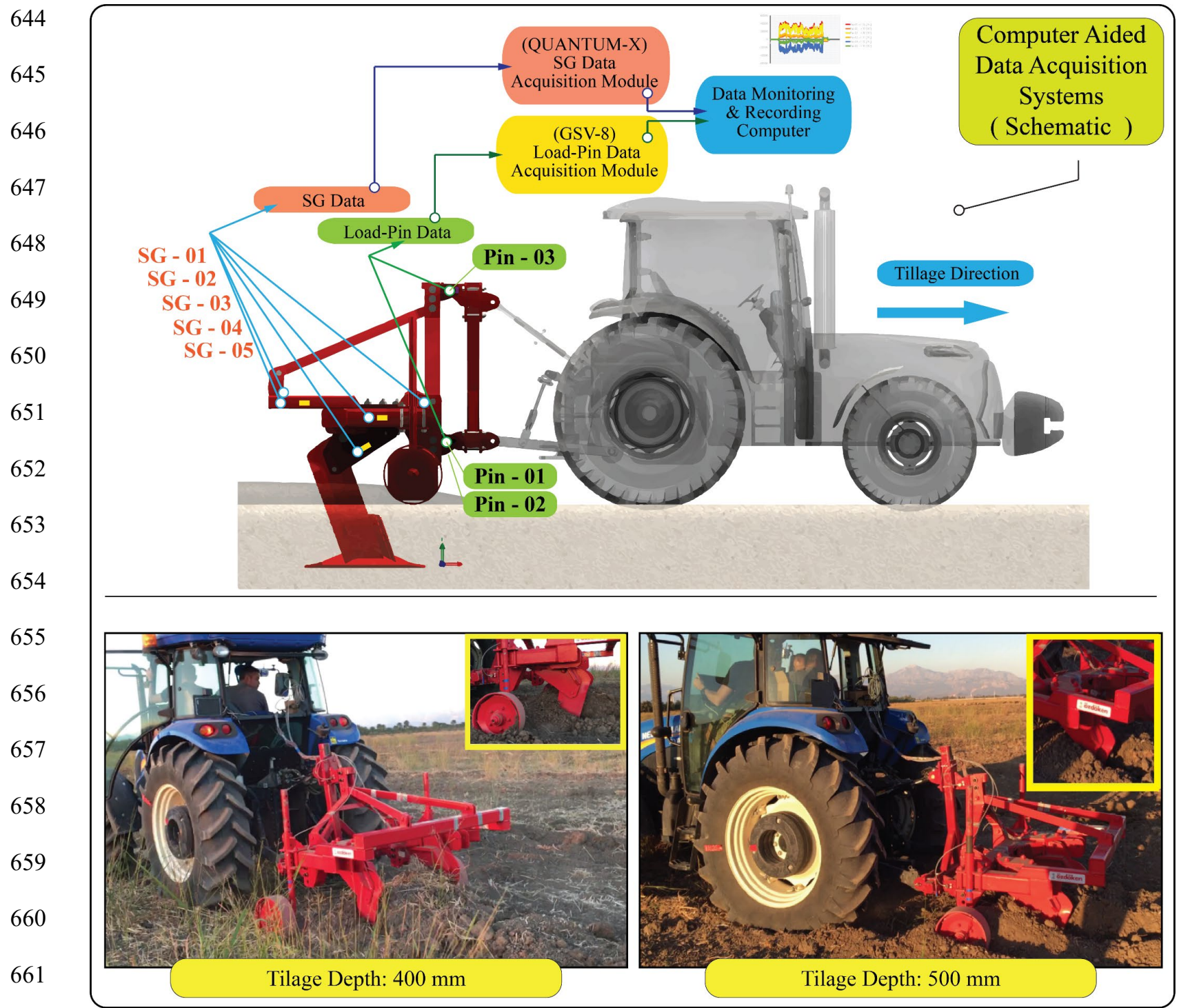

662

663

664

Figure 6. Schematic demonstration of the computer aided data acquisition systems and the pictures taken during field tests of nominal (tillage dept: $400 \mathrm{~mm}$ ) and worst-case (tillage dept: $500 \mathrm{~mm}$ ) tillage operations 


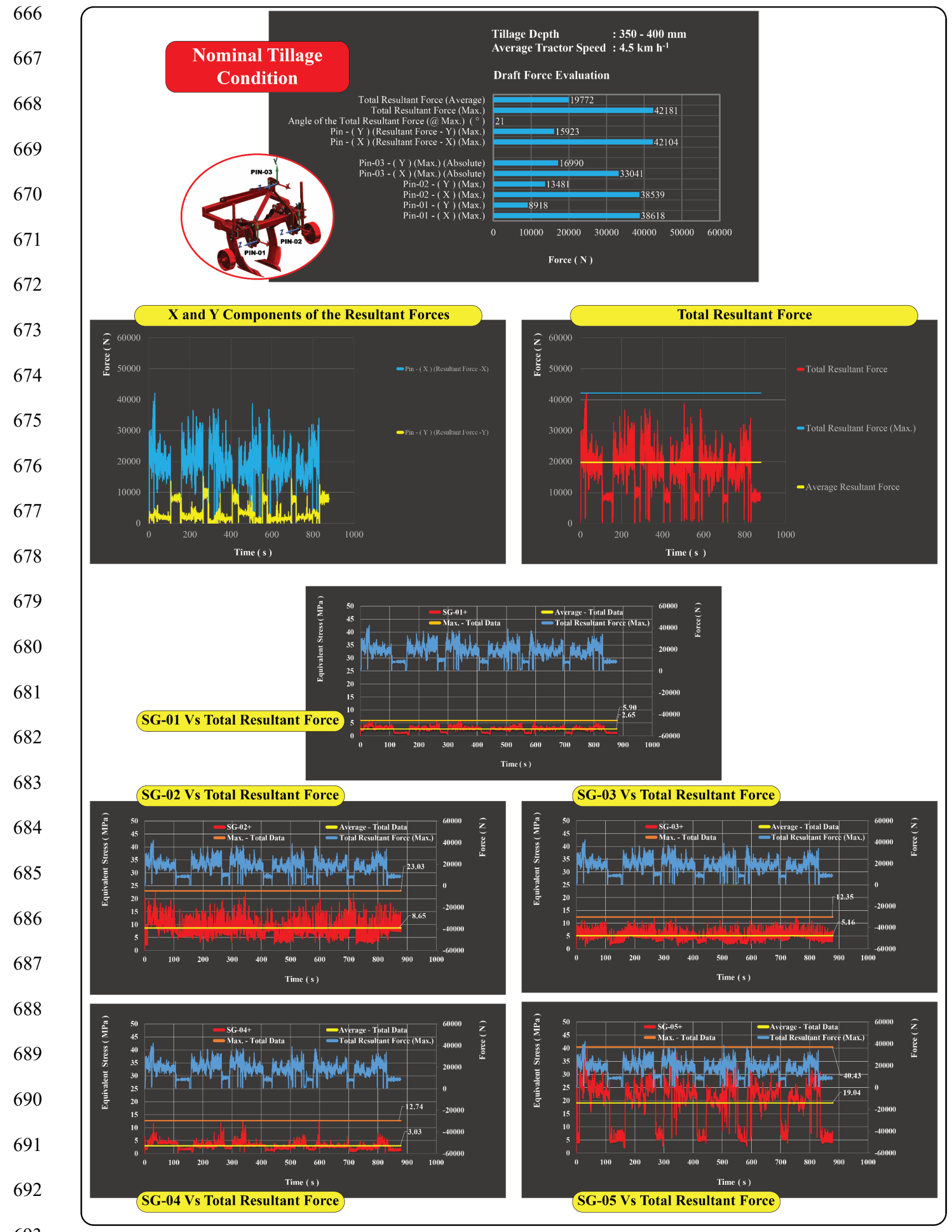

693

Figure 7. Field Test Results-01: Draft force and experimental stress values of nominal tillage condition 
SG-01 Vs Total Resultant Force

\section{Condition}
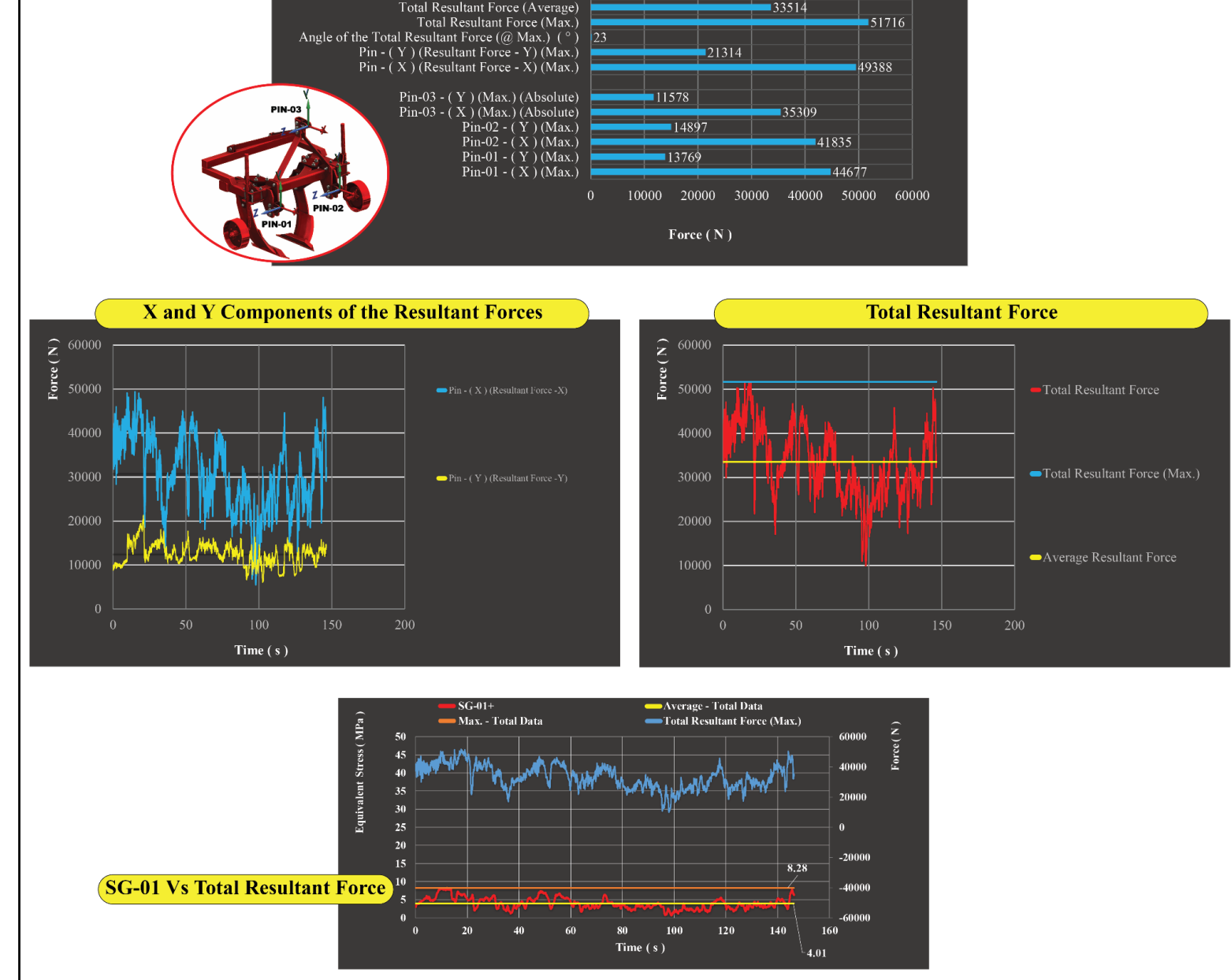

SG-01 Vs Total Resultant Force
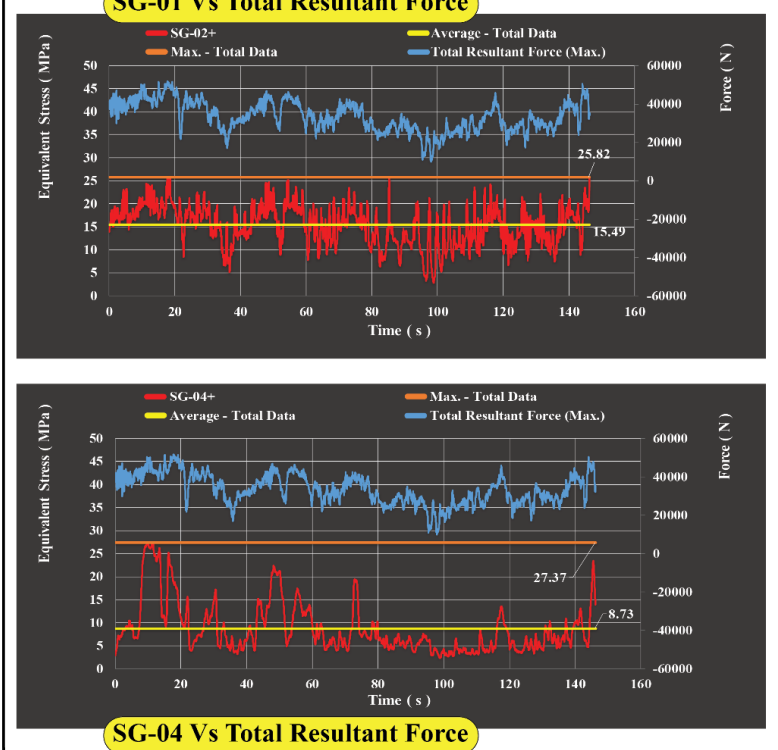

SG-04 Vs Total Resultant Force
SG-03 Vs Total Resultant Force
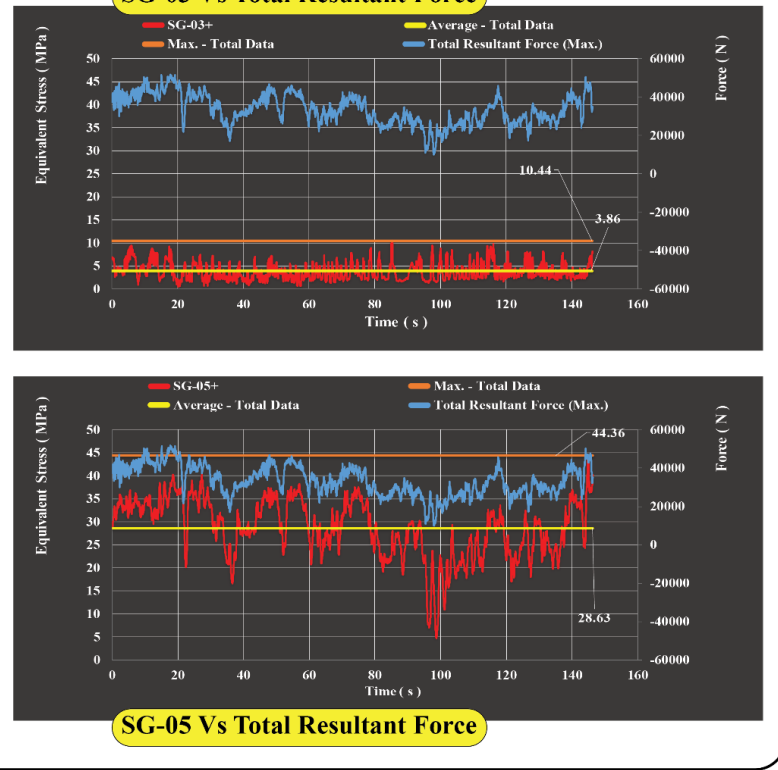

Figure 8. Field Test Results-02: Draft force and experimental stress values of worst-case tillage condition 
Figure 9. Some statistical details and visuals from the Para-Plow CAD modelling procedures 


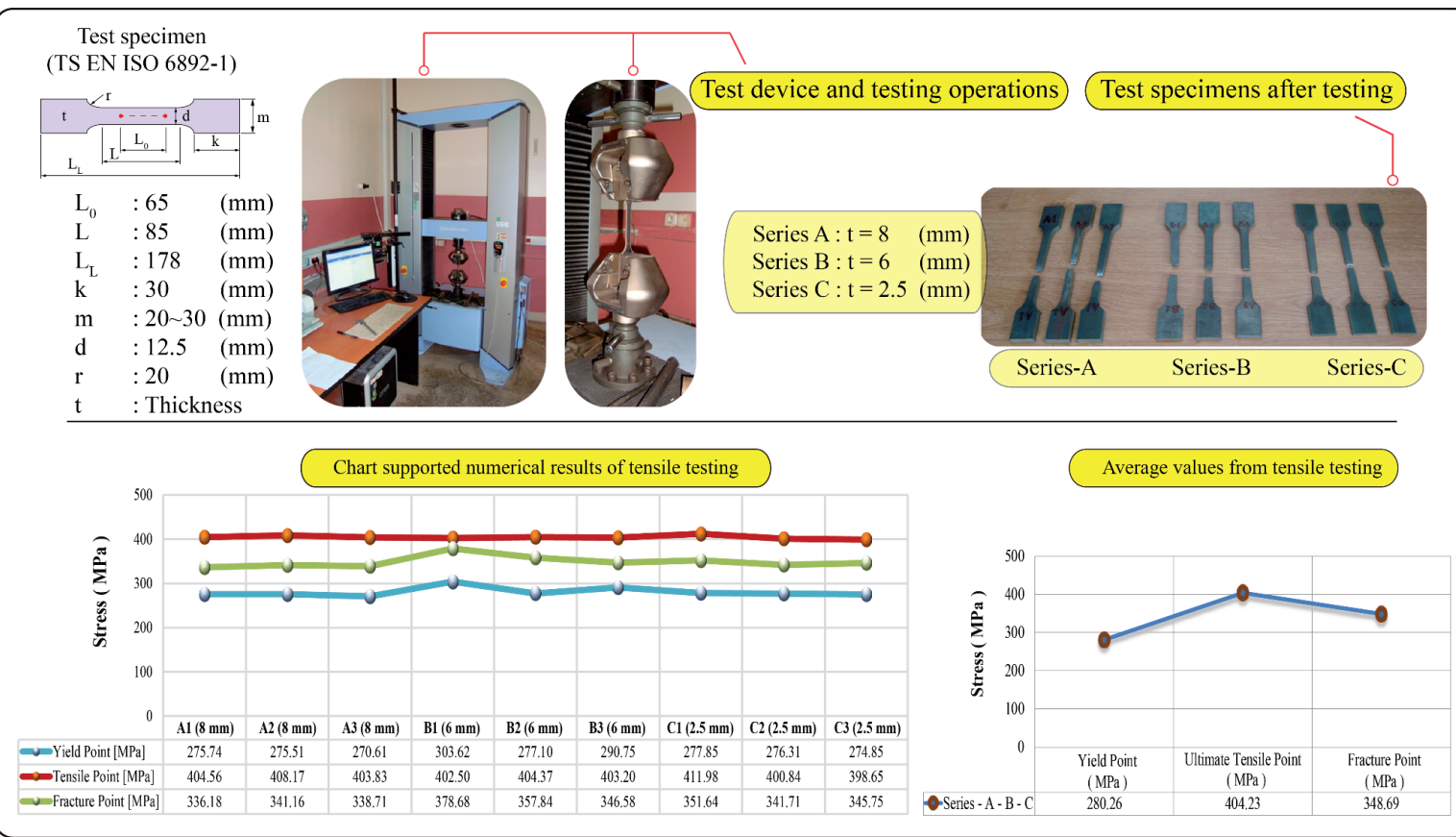

Figure10. Material testing results and determination of failure criteria (material yield point) 


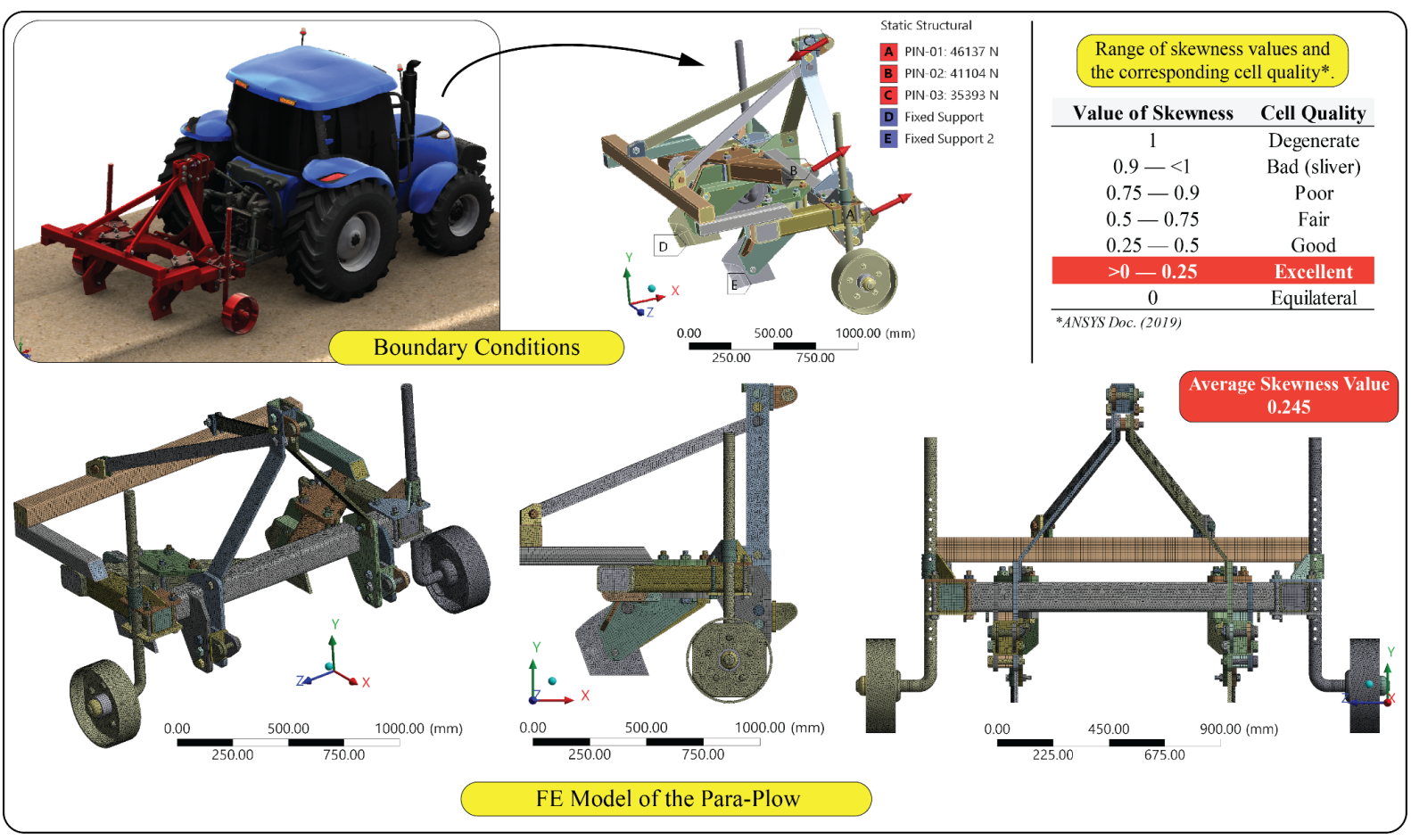

Figure 11. Boundary conditions assumed in the FEA, details and verification (Skewness check) of the FE model 768 


\section{Errors in FEA Approach}

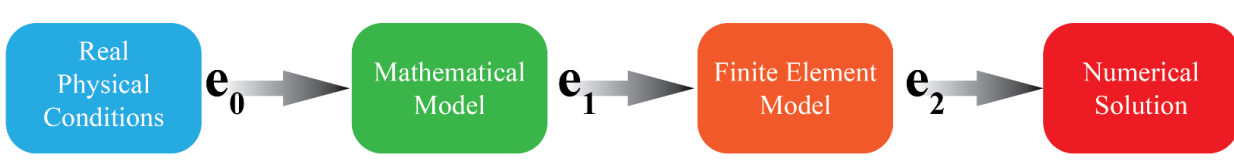

\section{- Calculation of the Singularity}

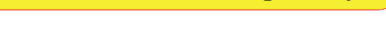

\section{D Element $\quad$ Rigid or elastic body}

\section{Singularity Check}

$\Delta=\frac{\sigma_{1}-\sigma_{2}}{\sigma_{1}} \times 100$

Singularity sign $===\Delta \geq 30 \%$

3D Element
at the high stress point

Surface of

the elastic body

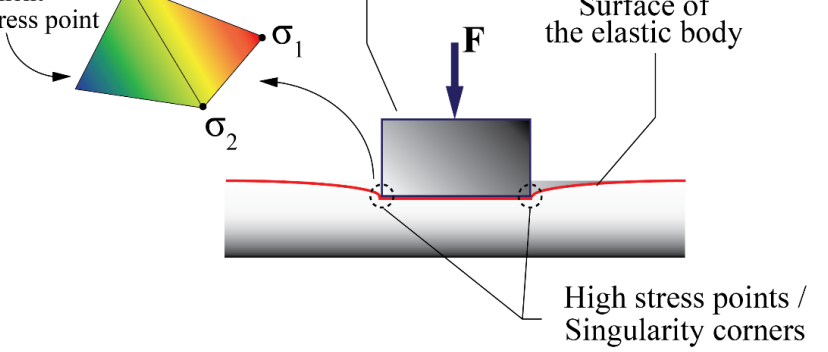

Sample Calculation for Singularity

Singularity corners

\section{A: Para-Plow FEA}

Equivalent Stress - Singularity Zone

Type: Equivalent (von-Mises) Stress

Unit: $\mathrm{MPa}$

270

250

250
100

100
83.3

66.7

50

33.3

16.7

0.0158 Min
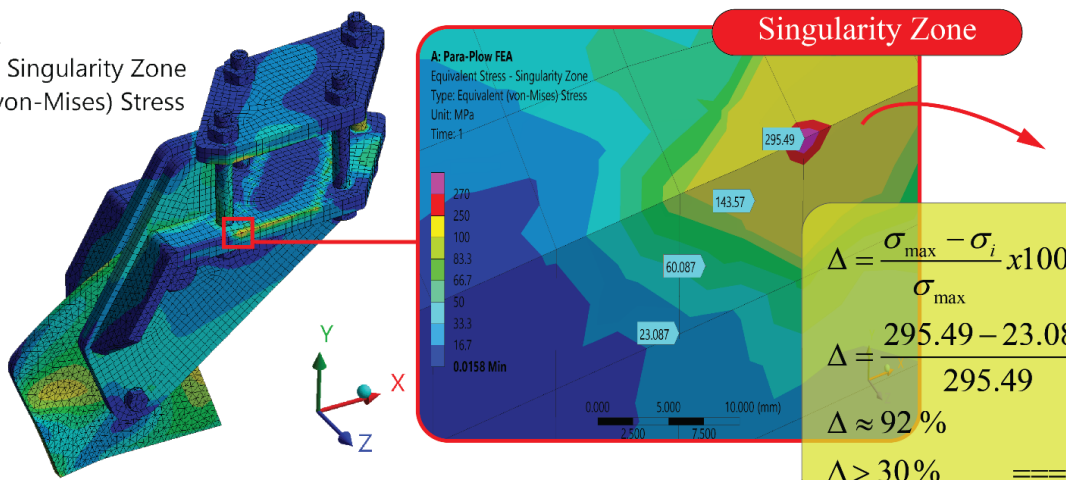

$$
\Delta=\frac{\sigma_{\max }-\sigma_{i}}{\sigma} x 100
$$

Singularity

Calculation

$\Delta=\frac{295.49-23.087}{295.49} x 100$

$\Delta \approx 92 \%$

$\Delta>30 \% \quad==$ SINGULARTY

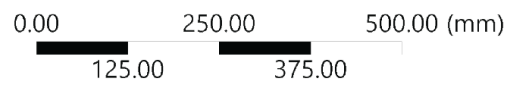

Figure 12. General errors in a FEA approach, singularity check and sample singularity calculation from the FEA results of the Para-Plow 


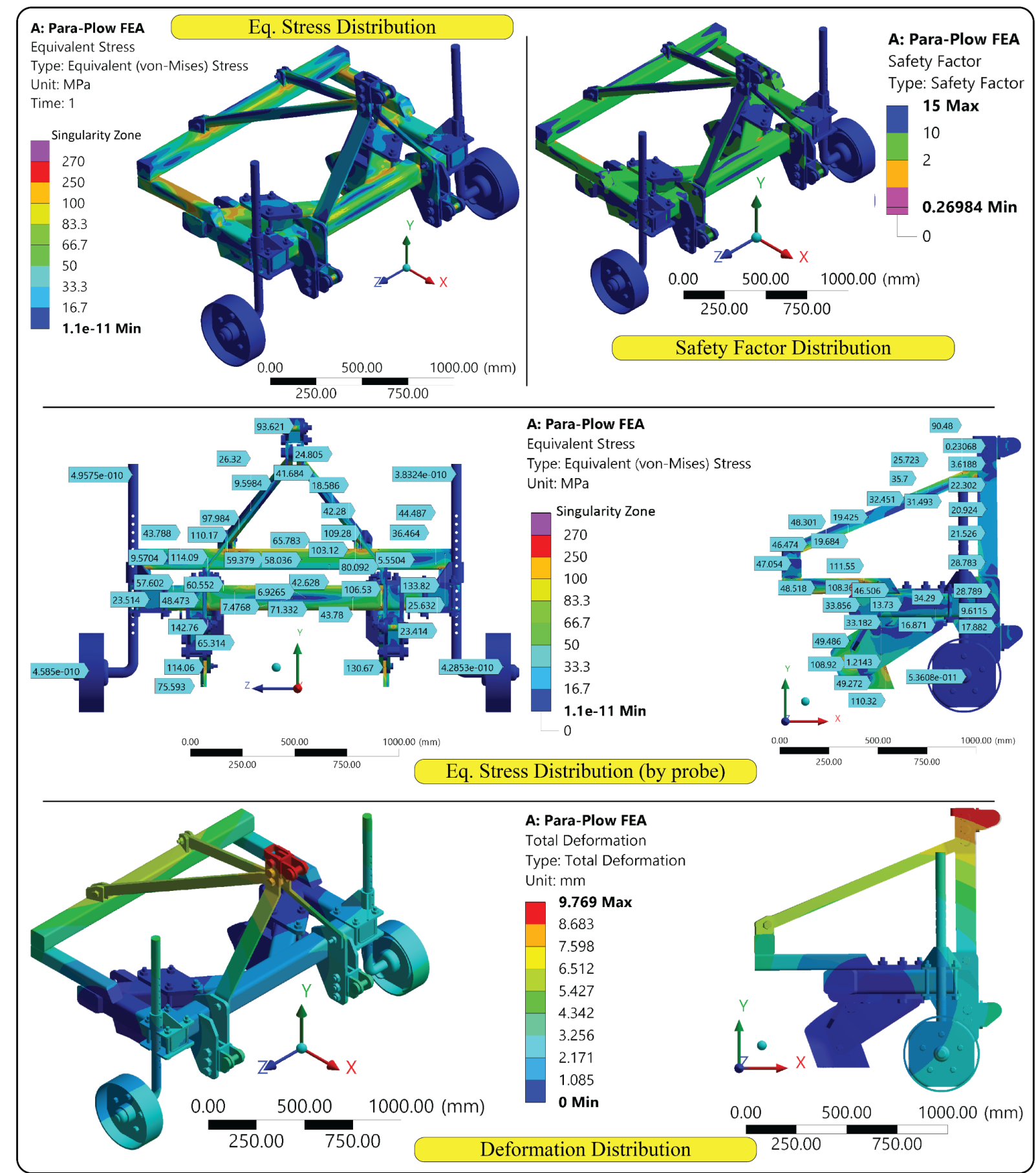

814

Figure 13. Output results of the FEA: Equivalent stress distribution, safety factor distribution and deformation distribution 


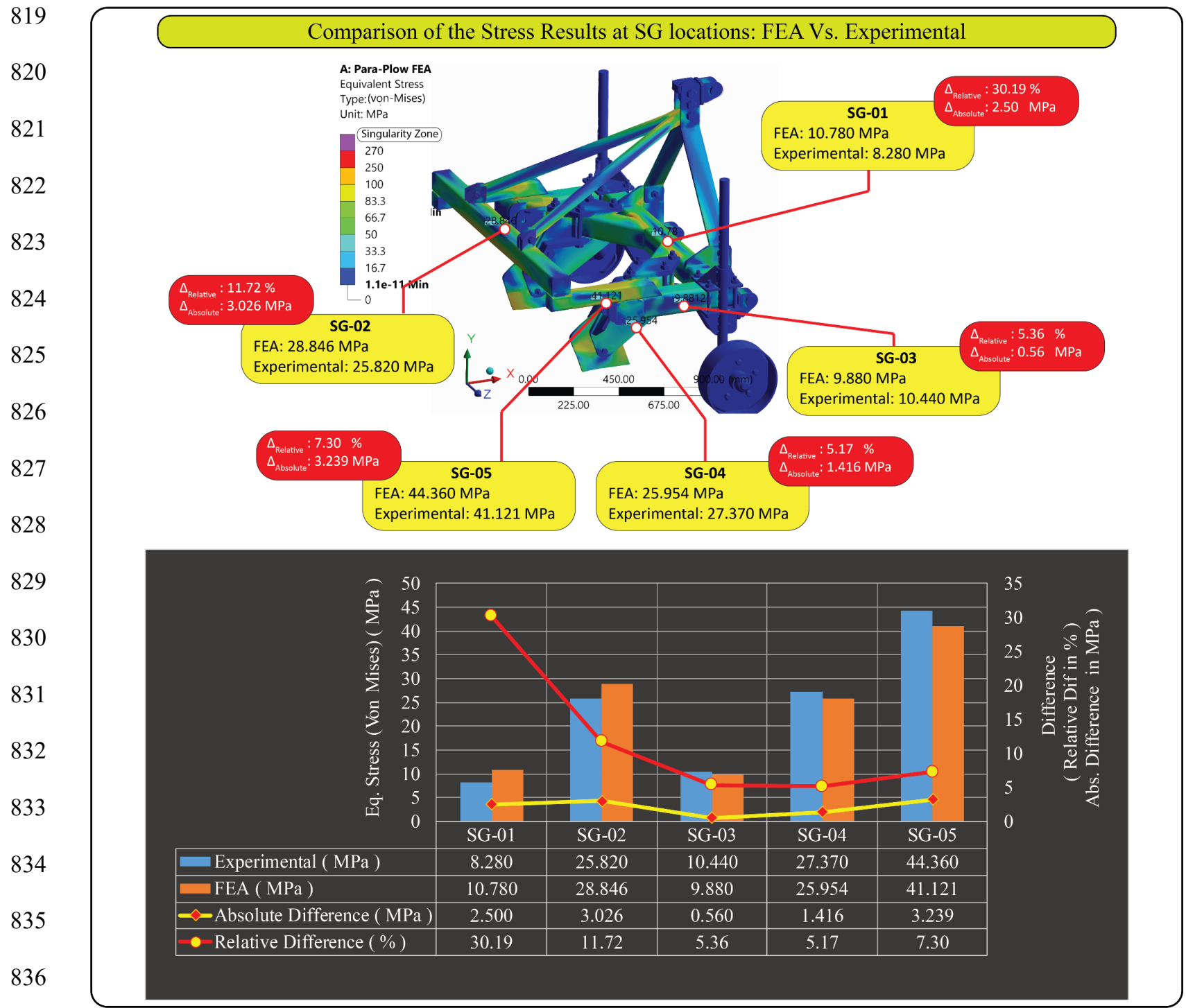

837

838 Figure 14. Validation study: Comparison of the experimental and the FEA stress results at SG locations 
Table 1. Draft force and equivalent (von Mises) stress values extracted from field tests

\begin{tabular}{|c|c|c|c|c|c|c|c|c|c|c|c|c|c|c|c|c|}
\hline \multirow{2}{*}{844} & \multirow{3}{*}{ Field Test Conditions } & \multirow{3}{*}{$\begin{array}{l}\text { Tillage } \\
\text { Depth } \\
(\mathrm{mm})\end{array}$} & \multirow{3}{*}{$\begin{array}{c}\text { Tractor } \\
\text { Speed } \\
\text { (Average) }\end{array}$} & \multirow{3}{*}{$\begin{array}{c}\text { Tractor } \\
\text { Wheel } \\
\text { Skidding } \\
\text { (Average) } \\
(\%)\end{array}$} & \multicolumn{2}{|c|}{ Draft Force } & \multicolumn{10}{|c|}{ Equivalent (Von Mises) Stress at SG Locations* } \\
\hline & & & & & \multicolumn{2}{|c|}{ (Resultant Force) } & \multicolumn{2}{|c|}{ SG-01 } & \multicolumn{2}{|c|}{ SG-02 } & \multicolumn{2}{|c|}{ SG-03 } & \multicolumn{2}{|c|}{ SG-04 } & \multicolumn{2}{|c|}{ SG-05 } \\
\hline 845 & & & & & $\begin{array}{l}\text { Max. } \\
(\mathrm{N})\end{array}$ & $\begin{array}{c}\text { Average } \\
(\mathrm{N})\end{array}$ & $\begin{array}{c}\text { Max. } \\
(\mathrm{MPa})\end{array}$ & $\begin{array}{l}\text { Average } \\
(\mathrm{MPa})\end{array}$ & $\begin{array}{c}\text { Max. } \\
\text { ( MPa ) }\end{array}$ & $\begin{array}{l}\text { Average } \\
\text { ( MPa ) }\end{array}$ & $\begin{array}{c}\text { Max. } \\
(\mathrm{MPa})\end{array}$ & $\begin{array}{l}\text { Average } \\
(\mathrm{MPa})\end{array}$ & $\begin{array}{c}\text { Max. } \\
(\mathrm{MPa})\end{array}$ & $\begin{array}{l}\text { Average } \\
(\mathrm{MPa})\end{array}$ & $\begin{array}{c}\text { Max. } \\
(\mathrm{MPa})\end{array}$ & $\begin{array}{l}\text { Average } \\
(\mathrm{MPa})\end{array}$ \\
\hline 846 & $\begin{array}{l}\text { Stage \#1: } \\
\text { Nominal Tillage Condition** }\end{array}$ & 400 & 5.0 & 12 & 42181 & 19772 & 5.91 & 2.65 & 23.05 & 8.65 & 12.35 & 5.16 & 12.74 & 3.03 & 40.43 & 19.84 \\
\hline 847 & $\begin{array}{l}\text { Stage \#2: } \\
\text { Worst-Case Tillage Condition }\end{array}$ & 500 & 1.2 & 40 & 51716 & 33514 & 8.28 & 4.00 & 25.82 & 15.49 & 10.44 & 3.86 & 27.37 & 8.73 & 44.36 & 28.63 \\
\hline 848 & $\begin{array}{l}\text { *SG: Strain Gauge } \\
\text { ** Operated tillage area: } 675\end{array}$ & & & & & & & & & & & & & & & \\
\hline
\end{tabular}

849

850

851 